\title{
Analysis on the Ideological and Political Construction of Colleges Piano Teaching in the New Era
}

\section{Tingting Rao}

Yangtze University School of Art, Jingzhou, Hubei, China

\begin{abstract}
There has been a wave of curriculum ideological and political construction in the teaching of professional subjects in colleges and universities, and the results have been remarkable. Curriculum ideological and political has provided guiding ideas and methods for the implementation of the task of cultivating people in professional subjects. Therefore, this article first briefly discusses the connotation of the ideological and political curriculum, and then considers the core and methods of the ideological and political construction of the piano teaching in colleges and universities, hoping to provide some references and inspirations for colleagues in the industry, so as to promote the smooth progress of the ideological and political construction of college piano teaching courses.
\end{abstract}

Key words: piano teaching; curriculum ideological and political; morality building and people cultivating

\section{Introduction}

General Secretary Xi Jinping has put forward higher requirements for China's education in the new era and clarified the guiding ideology. In the new era, domestic education must implement morality building and people cultivating, and solve the problems of who to train, how to train, and train for whom. In the piano teaching in colleges and universities, it is worth thinking about how to implement morality building and people cultivating, and realize implicit ideological and political education. Therefore, based on the thesis of General Secretary Xi Jinping, this article combines college piano teaching with curriculum ideological and political construction for analysis and discussion, in order to clarify the ways and methods to implement morality building and people cultivating in piano teaching.

\section{Curriculum Ideological and Political}

General Secretary Xi Jinping emphasized that each course must be well maintained and a good field of responsibility should be planted. Based on this important instruction, the country began to think about curriculum ideological and political construction, and gradually promote the reform and innovation of ideological and political education focused on it. Because the ideological and political courses are explicit and positive education, under the traditional educational concept, the ideological and political courses are "isolated islands" independent of various courses, which have unique advantages in explicit ideological and political education. However, the existence of the phenomenon of isolated islands leads to the fact that the explicit education of the ideological and political curriculum cannot fulfill the fundamental task of cultivating people. The emergence of curriculum ideological and political education is to solve the isolated island problem of 
ideological and political education. It includes implicit ideological and political education to ensure the complete implementation of the fundamental task of morality building and people cultivating.

Curriculum ideological and political is a comprehensive curriculum concept. Taking the morality building and people cultivating as the standard, it requires the organic combination of professional subjects and ideological and political courses, so as to realize the integration of explicit and implicit education. Due to the isolated island problem of ideological and political courses and the not enough depth of original ideological and political education work, it is special emphasis on hidden education in curriculum ideological and political, that is, the teaching of professional subjects must incorporate the content of ideological and political education, integrate with professional knowledge and skills, and integrate the goals of ideological and political education into professional subject to promote professional disciplines to become part of the school education curriculum system, and then promote the integrity of the education system. Therefore, curriculum ideology is essentially to foster morality, and professional disciplines are not only a position for imparting knowledge and skills, but also a position for students to learn the truth of life.

Since the 18th National Congress of the Communist Party of China, the reform of ideological and political courses in colleges and universities has achieved remarkable results. Especially after the ideological and political construction of courses, the isolated island problem of ideological and political education has gradually disappeared, and the problem of ideological and political courses and professional courses has gradually weakened, which is the most valuable place for curriculum ideology.

Curriculum ideological and political education is based on professional courses to a certain extent. Courses of various disciplines are the foundation of the education process and are also key points in the education reform. Therefore, curriculum ideological and political construction must be clear about curriculum theory. In the construction of curriculum ideology in piano teaching, we should also clarify the nature of the piano curriculum and its development rules, as well as the curriculum goals, concepts, content, and methods. In the mid-nineteenth century, British scholars put forward the classic proposition "What is the most valuable knowledge", and thus began the study of the value of various disciplines for human survival and development. However, the piano course is limited by the school's teaching time and cannot fully cover all the knowledge of this course, so the choice of famous knowledge should be emphatically considered, and systematic and simplicity should be respected. Systematic emphasizes that the course is a system, rather than a single course, while simplicity emphasizes the learner's necessary generalization, refinement and simplification of knowledge. In the construction of ideological and political courses in piano teaching, the following questions should be considered: What are the ideological and political requirements for talent training in universities? What content does ideological and political quality include at the knowledge level? Which of the most valuable knowledge is? Among these most valuable knowledge, which ones cannot be covered by the existing ideological and political curriculum system? Can this knowledge be made up through the piano course system or realized through the integration of the two?

\section{Thoughts on Piano Teaching in Colleges and Universities Based on Curriculum Ideological and Political}

There are usually two types of courses in piano teaching in colleges and universities, namely theoretical lessons and practical lessons. And the practical lessons are the most important part of piano teaching. The piano is a tool, and the instrumental nature of piano lessons is very prominent, however, piano performance can also express the thoughts and emotions of music and players, so piano teaching not only allows learners to master piano playing skills and music theory (part), but also allows learners to experience the truth, goodness and beauty of human beings through learning piano playing. For example, Beethoven's piano sonatas, especially the piano music composed by Beethoven in his later period, 
built a bridge between classicism and romanticism. The five piano pieces composed by Beethoven in his late period were very difficult to perform, but Beethoven's creative idea was not to show off his piano skills, but to use music to express his thoughts and emotions more deeply. Therefore, Beethoven's late works are more like the cry of the soul. In some works of this period, you can often see the marks of PP/PPP or FF/FFF, which are focused on highlighting contrast and expressing inner emotions with dynamic changes. Take pathetique as an example, the first half of the main sentence of the first part is marked with F, but the second half of the sentence becomes P. This strong or even abrupt melody contrast and intensity changes are essentially expressions of intense emotions. Combining Beethoven's experience, he was facing a crisis of deafness at that time, and all progressive ideas were forbidden under the social background (feudal restoration), so we can feel the overwhelming social pressure and the author's ideals and beliefs -- adherence to the republican thought of freedom and equality in the heavy chords of the music. This theme is also brought out by the constant repetition and contrast of the common chords and octave melody in the high range.

It is no doubt that music itself has the function of expressing emotions. Even though people who have not undergone special music training can also generate emotional feelings from music, which is a natural and primitive aesthetic feeling. Morality building and people cultivating emphasize the morality building firstly, and then followed by people's cultivating. Ideological and political theory is the main position of moral education. Based on the previous analysis, the most valuable knowledge in piano teaching is aesthetic education, but aesthetic education is not available in ideological and political theory classes. Generally speaking, aesthetic education is the foundation of moral education and determines its level. Therefore, the ideological and political construction of piano teaching courses should be considered from the perspective of aesthetic education to create a suitable curriculum ideological and political system.

\section{Analysis of the Ideological and Political Construction of Piano Teaching in Colleges}

From the perspective of knowledge selection, the knowledge selection of piano courses must cover the basic categories, propositions, principles and methods of piano courses and majors, and must meet the requirements of social changes for the cultivation of talents in colleges and universities. From ancient times to the present, there have been many schools of thought in the education field with different viewpoints. However, the educational circle has always had a consensus that it is necessary to cultivate the people needed for social development. By extension, it is necessary to cultivate people required by social development, knowledge accumulation, cultural inheritance, national survival, and system operation. Therefore, the curriculum ideological and political construction should not only include the content of the ideological and political courses, but also include some contemporary knowledge, including the interpretation of the connotation of the original ideological and political theory in view of the new problems and new challenges of the new era, Xi Jinping's thought on socialism with Chinese characteristics in the new era, the objective trend adapting to the development of the times, and the qualities and capabilities should have for talent growth that other countries or organizations first put forward. Piano courses have limitations in terms of basic categories, propositions, principles and methods, and its most valuable knowledge is music aesthetics. Music has no national boundaries, and Chinese stories can be better told through music. But musicians have national boundaries. The construction of ideological and political courses in piano teaching is aimed at human education, the aesthetic ability is cultivated through piano teaching to encourage learners to realize the truth of the life.

Curriculum ideological and political construction should achieve the level that "I don't know who you are, but I know who you are for, and you also let me know who I am for in the future." This sentence is an evaluation of professional course teachers, and also reveals the significance of curriculum ideological and political construction. Piano teaching is highly instrumental, and the teaching is mostly based on practical teaching, but practice often turns into training of piano 
playing skills, so in fact, it cannot transfer the most valuable knowledge of piano teaching. Therefore, it is necessary to integrate basic courses such as audio-visual ear training and music analysis in the practical courses, and use comprehensive content to realize the goal that theory guides practice, and practice verifies theory, so as to encourage students to understand moral knowledge from practice.

The subject of this article is piano, which belongs to a single subject, the problem of knowledge fragmentation after curriculum ideological and political construction may appear. Therefore, in the curriculum ideological and political construction, the piano teaching should be reformed around the curriculum integration ideas. Piano teaching is a basic course for vocal music and dance. It has a natural close relationship with important professional courses such as sight singing and ear training courses and musical pattern analysis courses. Therefore, we should build a curriculum ideological and political system by integrating ideas to avoid knowledge fragmentation caused by a single curriculum. From the perspective of cultivating people, piano teaching is to cultivate talents with piano performance and music literacy. Piano performance requires learners to achieve the synergy of the three senses in hearing, touch and vision. The synergy of three senses highlights the beauty of music, but the beauty of music is not only expressed by musical elements such as melody and rhythm, but also expressed by emotion, which is the most valuable knowledge in piano teaching, so the emotion in the music must be clear. In terms of the purpose of building morality (or aesthetic education), in the course of ideological and political construction, it is necessary to encourage students to experience the emotions in the music, and to play the piano with full emotions. It is important for students to master piano playing skills in piano teaching, but emotional expression is more important. All performance skills should serve the expression of emotion. Otherwise, no matter how good performance skills are, there is no emotional resonance in the music played, and such piano performance is soulless.

It can be concluded that the ideological and political construction of piano teaching curriculum is to help students complete piano performance training, while guiding students to improve their understanding of music emotions and natural music perception, and form a higher level of aesthetic awareness and standards. For example, in the teaching of Appassionata (one of Beethoven's piano sonatas), students should be guided to understand Beethoven's character (to hold the throat of fate) and his background when creating passion, and laying an emotional tone for students -- confidence, selfimprovement, lofty sentiments and passion. Then introducing the analysis of the musical composition, and let the students master the emotional expression techniques in the music, such as contrast, harmony, dynamic changes, etc., and then let students conduct audiovisual ear training, master the technique of performance, and finally play with emotion.

\section{Conclusions}

In summary, morality building and people cultivating is a fundamental task that must be implemented in the current educational circle. General Secretary Xi Jinping's important speech has laid an important foundation for the implementation of morality building and people cultivating in subject teaching. The emergence of curriculum ideology and politics has also contributed to the development of ideological and political courses. A solution to the problem of two skins in professional courses is proposed, that is, the ideological and political elements in the subject teaching should be explored, and the elements that are not available in the ideological and political courses should also use appropriate methods to achieve an effective combination of subject teaching and curriculum ideology through integrated. The most valuable thing in piano teaching is the beauty of music. Therefore, aesthetic education should be used as an entry point in the ideological and political construction of piano teaching. While urging students to experience beauty through learning piano, they should refine moral knowledge from music.

\section{Conflicts of Interest}

The author declares no conflicts of interest regarding the publication of this paper. 


\section{References}

[1] Wu Y.Q. (2018). Discussion of Three Emphasis on Promoting "Curriculum Ideological and Political" in Universities. The Party Building and Ideological Education in Schools, (1): 67-69.

[2] He H.J. (2017). The Internal Logic and Construction Strategy of the Development from "Ideological and Political Course" to "Curriculum Ideological and Political". Ideological and Political Education Research, 33(5): 60-64.

[3] Zhao J.L. (2018). Cultivation of Comprehensive Ability in Piano Performance Teaching. Northern Music, 38(3): 159-160.

[4] Hu H. (2017). Research on the Cultivation of Students' Sense of Structure in Piano Playing Teaching. Hei He Jiao $Y u,(2): 65-67$. 